\title{
EFFECTS OF NANO COPPER USED IN SEED TREATMENT FOR GERMINATION, GROWTH, AND PRODUCTIVITY OF MAIZE
}

\author{
Le Thi Thu Hien ${ }^{1,2 *}$, Nguyen Tuong $\operatorname{Van}^{3}$ \\ ${ }^{1}$ Institute of Genome Research, VAST \\ ${ }^{2}$ Graduate Universty of Science and Technology, VAST \\ ${ }^{3}$ Institute of Biotechnology, VAST
}

\begin{abstract}
Recently, metal and other nanoparticles have been widely used to improve crop growth and development, reduce used chemical amount, increase safety of agricultural products and prevent soil and water pollution. Seed treatment technology with metal nanoparticles to stimulate seed germination and improve crop yields has been reported in several studies. In order to assess the safety of the use of metal nanoparticles in agriculture production, in this study the effect and safety of seed treatment with nanoparticles $(\mathrm{nCu})$ prior to sowing on the germination, growth, development, productivity and quality of maize (Zea mays L.) were evaluated in the field conditions. Seeds of maize cultivar LVN 092 were treated with $\mathrm{nCu}$ at different concentrations before planting. Germination and plant growth rates, plants yield and grain nutrition were monitored and evaluated. The obtained results showed that treatment of maize seed with $\mathrm{nCu}$ at a concentration of $20 \mathrm{mg} / \mathrm{kg}$ seed increased germination after 7 days of sowing as well as the theoretical and actual yields compared to the control and the treatment of $1000 \mathrm{mg} \mathrm{nCu} / 1 \mathrm{~kg}$ seeds. Other agricultural characteristics, such as the development rate, plant height, grain nutritional content including moisture, ash, total fiber, crude protein, minerals were not significantly between treatments and the control. Therefore, the seed treatments with metal nanoparticles can be contribute to improve agriculture production without impact to quality of crops.
\end{abstract}

Keywords: Zea mays, metal nanoparticles, seed treatment, plant growth development.

Citation: Le Thi Thu Hien, Nguyen Tuong Van, 2018. Effects of nano copper used in seed treatment for germination, growth, and productivity of maize. Academia Journal of Biology, 40(4): 91-101. https://doi.org/https://doi.org/10.15625/2615-9023/v40n4.13580.

*Corresponding author email: hienlethu@igr.ac.vn

Received 25 July 2018, accepted 5 December 2018

\section{INTRODUCTION}

Nowadays, nanomaterials have been wildly used in agriculture as fertilizers, growth regulators, plant protection agents to stimulate crop productivities due to their particularly small size and unique properties (Roduner, 2006; Adhikari et al., 2010). A number of studies focused on the effectiveness and safety of using metal nanoparticles in agriculture production (Alloway, 2008; Sheykhbaglou et al., 2010; Rico et al., 2011; Kole et al., 2013; Begum et al., 2014). Among the micronutritinal elements required for normal plant development, manganese $(\mathrm{Mn})$, copper $(\mathrm{Cu})$, iron $(\mathrm{Fe})$, zinc $(\mathrm{Zn})$, boron $(\mathrm{Bo})$, chlorine $(\mathrm{Cl})$, 
molybdenum (Mo), and cobalt (Co) are essential for the growth of plants (Alloway, 2008). The providing of these substances to plants directly through leaves or indirectly to the soil had contributed to the plant development and the fertility of the soil (Peteu et al., 2010). Bitter melon (Momordica charantia) seed treatment with fullerol $\left(\mathrm{C}_{60}(\mathrm{OH})_{20}\right)$ increased the yield, fruit length, fruit number/plant and fruit weigth up to 54 , 20,59 and $70 \%$, respectively. The content of the two anticancer agents cucurbitacin-B and lycopene in fruit incrased 74 and $82 \%$, respectively. The content of charantin and insulin, two active substances to treat diabetes, also increased by 20 and $91 \%$ (Kole et al., 2013). Sheykhbaglou et al. (2010) conducted the the experiment on the effect of $\mathrm{FeO}$ nanoparticles on the yield of soybean (Glycine max) grown in the field and found that at the concentration of $0.5 \mathrm{~g} / \mathrm{dm}^{3}, \mathrm{FeO}$ nanoparticles helped to increase yield to the impressed level, reaching $48 \%$ compared to the control.

There are also several studies to evaluate the undesirable effects of nanomaterials on plants and indicated that the majority of nanoparticles were beneficial or have no significant effect on plant growth; adversely effects on certain crops were reported in limited casses (Rico et al., 2011; Begum et al., 2014). When evaluating the possible toxicity of the five nanoparticles, Lin \& Xing (2007) found that only $\mathrm{Zn}$ and $\mathrm{ZnO}$ nanoparticles inhibited germination and root development in six plant species. Similarly, when seed of maize, alfalfa (Medicago sativa), cucumber (Cucumis sativus) and tomato (Lycopersicon esculentum) treated with nano ceria $(\mathrm{Ce})$ at concentrations from 0 to $4000 \mathrm{mg} / \mathrm{L}$, germinaton cability of maize, tomato and cucumber decreased 30, 30 and 20\%, respectively, compared to the control at 2000 $\mathrm{mg} / \mathrm{L}$ dose use. While roots of maize and cucumber were stimulated, they were decreased for alfalfa and tomato. Most of the
nano-Ce concentrations boosted sprouting in all four species (Lospez-Moreno et al., 2010). The development of Cucurbita pepo (Cucurbitaceae) was decreaed by $\mathrm{Ag}$ and $\mathrm{Cu}$ nanoparticles (Musante \& White, 2010). Very few studies have been conducted to evaluate the accumulation of nanoparticles in plant species and the presence of these materials in food crops. However, it can be seen that most of reported studies were carried out under conditions of high concentrations of nanoparticles used.

In Vietnam, the nanomaterials have recently been used as fertilizer or plant growth regulatory of many cultivation species. Several studies have been conducted to evaluate the role of $\mathrm{Fe}, \mathrm{Co}$ and $\mathrm{Cu}$ metal nanoparticles in the growth and development of soybean, maize and vegetables. Bui (2009) had produced silver nanoparticles $(\mathrm{Ag})$ by gamma Co-60 radiation to treat fungal blast disease (Piricularia oryzae Cavara), grain rot disease (Pseudomonas glumae Kurita et Tabei). Pesticides, which are effective to manage pink fungus Corticium salmonicolor and white powdery mildew Oidium heveae of rubber trees, were produced from $\mathrm{Cu}$ nano solution by Nguyen et al. (2011). Using solgel method, Dong et al. (2013) prepared a white colour and dispersibility $\mathrm{TiO}_{2}$ solution to inhibit the growth and symptoms of tobacco mosaic virus (TMV) in plants. Duong et al. (2015) studied the in vitro growth and development of Chrysanthemum sp. in medium supplimented with $\mathrm{nFe}$. The obtained results indicated that the growth of young shoots was excessed compared to the controls, leaves stayed green and root formation was faster in the presence of $\mathrm{nFe}$ and $\mathrm{nFe}$-EDTA. In addition, $\mathrm{nAg}$ also had a positive effect on the growth and development of strawberry (Fragaria sp.) and gerbera (Gerbera sp.) cultured in vitro (Duong et al., 2014). They also demonstrated the effect of $\mathrm{Ag}$ nano on the growth of Chrysanthemum morpholium in hydroponic systems. The plants were speeded 
after 2 weeks in the medium added with 7.5 ppm nAg. The present of nAg also inhibited the growth and development of 8 bacterial and 3 fungal species. In addition, such $C$. morpholium plants gave a higher survival rate $(100 \%)$ and better growth than other treatments when transferring to the green house (Hoang et al., 2016). For maize, Fe, Co, and $\mathrm{Cu}$ nanoparticles were reported to increase maize productivity (Churilov et al., 2012; Ngo et al., 2013, 2014).

This study aims to assest the safe use of nanometal particles, and the effect of $\mathrm{Cu}$ nanoparticles $(\mathrm{nCu})$ at the optimal and 500 fold higher concentrations was monitored and evaluated. The results contributed to the safe application of nanomaterials to increase productivity and quality of agricultural products.

\section{MATERIALS AND METHODS}

Hybrid maize cultivar LVN 092, which was characteried by low ear insertion, strong sterm and root system, was provided by the Maize Research Institute. Shiny, uniform in size and free from damage seeds were carefully selected for this study.

$\mathrm{Cu}$ nanoparticles are provided by the Institute of Environmental Technology, Vietnam Academy of Science and Technology within the framework of the Project: "Application of nanotechnology in agriculture". Seeds were treated with $\mathrm{nCu}$ at three different concentrations of nCu: (i) optimal concentration of $20 \mathrm{mg} / 1 \mathrm{~kg}$ seed (F1) and (ii) $1000 \mathrm{mg} / 1 \mathrm{~kg}$ seed (F2); (iii) the control seeds were wetted with water (Control). Solution of $\mathrm{nCu}$ was prepared by dispersing the metal nanoparticles in water and placed in ultrasound $(800 \mathrm{~W}, 20 \mathrm{kHz})$ for 30 minutes. Next, the selected seeds $(1 \mathrm{~kg})$ were mixed with the prepared $\mathrm{nCu}$ solution, incubated for 45 minutes, removed from solution and dried in the air for 1-2 hours before sowing (Churilov et al., 2000; Churilov, 2010).

\section{Cultivation}

After $\mathrm{nCu}$ treatments, seeds were dried and sown in 9 expreriment plots. Each plot consisted of 7 rows of $10 \mathrm{~m}$ in length, a distance of row and plant in a row to be $70 \times$ $25 \mathrm{~cm}$, corresponding to $49 \mathrm{~m}^{2} /$ plot. Cultivation and fertilization methods were done in accordance with Trial Regulations 0156-2011 of Ministry of Agriculture and Rural Development. The experiments were conducted in the Summer-Autumn cultivation season of 2016 at the Maize Research Institute, Vietnam Academy of Agricultural Sciences (Dan Phuong, Ha Noi).

\section{Germination assay}

Germination percentage (GR) and seedling establishement (SE) were monitored and culculated after 7 days, in which GR = [Germinated seeds/total $\times 10 \% ; \mathrm{SE}=[$ Number of formed seedling/total] $\times 100(\%)$.

\section{Growth and development of maize plants}

These morphological characteristics were evaluated via plant height (measured from the ground to the leaf end) in centimeter at 30, 40 and 50 days after planting.

\section{Theoretical and actual yields}

In each plot, five plants in two random rows were measured. Theoretical and actual yield (weight/ha) are calculated according to the following formulars:

TY $($ Theoretical yield $)=$ No of plants $/ \mathrm{m}^{2} \times$ No of ears/plant $\times$ No of row/ear $\times$ No of grains/No of rows of grain $\times 1000$ grain weight $/ 10.000$

AY $($ Actual yield $)=\left(\mathrm{P}_{1} / \mathrm{S}_{0}\right) \times\left(\mathrm{P}_{2} / \mathrm{P}_{3}\right) \times$ $\left(100-\mathrm{A}_{0}\right) /(100-14) \times 10^{2} \mathrm{~m}^{2}$

In which: $\mathrm{P}_{1}$ : fresh ear weight; $\mathrm{A}_{0}$ : grain moisture; $\mathrm{S}_{0}$ : plot acreage; $\mathrm{P}_{2}$ : grain weight of samples (weighted at the time of measuring the seed moisture content " $\left.\mathrm{A}_{0} "\right) ; \mathrm{P}_{3}$ : fresh seed weight. 


\section{Nutrient analysis}

Water content (\%) was determined by the Benjamin and Grabe methods (1988). Specifically, $10 \mathrm{~g}$ of grains was placed in a porcelain bowl and dried at $105^{\circ} \mathrm{C}$ for at least 6 hours to reach a constant weight. Following, the porcelain cup was cooled in a desiccator for about 25 to 30 minutes and then weighed with analytical balance (accuracy of 0.0001 g). Water content was calculated according to the formular: Water content $(\%)=\left[\left(\mathrm{m}_{1}-\mathrm{m}_{2}\right) /\right.$ $\left.\left(\mathrm{m}_{1}-\mathrm{m}\right)\right] \times 100(\%)$; in which $\mathrm{m}, \mathrm{m}_{1}$ and $\mathrm{m}_{2}$ are the weights of the porcelain cup, porcelain cup containing $10 \mathrm{~g}$ sample before and after dried at $105^{\circ} \mathrm{C}$, respectively.

The ash content was determined using the high heat $\left(550-600^{\circ} \mathrm{C}\right)$ to completely burn organic substances (AOAC, 1999). A total of $5 \mathrm{~g}$ of the sample was placed into the cup and baked in a oven at $600^{\circ} \mathrm{C}$ for 6 to 7 hours until ash having white color. The porcelain cup was cooled in a desicator and weighed with an accuracy $0.0001 \mathrm{~g}$. Ash contain was measured as the following fomular: Ash content $(\%)=$ $\left[\left(\mathrm{m}_{2}-\mathrm{m}\right) /\left(\mathrm{m}_{1}-\mathrm{m}\right)\right] \times 100(\%)$, in which $\mathrm{m}, \mathrm{m}_{1}$ and $\mathrm{m}_{2}$ are the weights of the porcelain cup, porcelain cup containing $5 \mathrm{~g}$ sample before and after heated at $600^{\circ} \mathrm{C}$, respectively.

Total dietary fiber (TDF) was determined by enzyme-mass method according to TCVN 9050:2012. Seeds were hydrolyzed by heat-stable $\alpha$-amylase, protease and amyloglucosidase to remove starch and protein. Subsequently, the soluble fiber in the hydrolyzed solution was precipitated with ethanol before filtration and the total fiber residue was washed with ethanol and acetone, dried at $105^{\circ} \mathrm{C}$, cooled in a desiccator and weighed using a balance with accuracy at $0.0001 \mathrm{~g}$. Total dietary fiber was determined as following formula: TDF (\%) = [(precipitated pellet weight-ash weight-protein weight)/ initial sample weight] $\times$ $100(\%)$.

Crude protein content: The crude protein content was determined using Kjeldahl method indicated in TCVN 10791:2015. Total $1 \mathrm{~g}$ of the sample was added into digestion vessel with $10 \mathrm{~g}$ of potassium sulphate, $0.7 \mathrm{~g}$ of mercury oxide and $20 \mathrm{~mL}$ of concentrated sulfuric acid. The mixture was heated slowly until foam appearance, boiling and becoming transparent. The solution was then cooled and added with $90 \mathrm{~mL}$ distilled water and then 80 $\mathrm{mL}$ of $\mathrm{NaOH} 2 \mathrm{M}$ to form two layers in the extractor. Condensed ammonia was collected into a tube containing $50 \mathrm{~mL}$ boric acid and methyl red indicator. The condensate $(50 \mathrm{~mL})$ was recovered and titrated by $\mathrm{HCl} 0.1 \mathrm{M}$. The percentage of nitrogen was assessed as follows: Nitrogen $(\%)=[$ Acid volume $\times$ No of mol of standard acid]/[Sample weight $] \times$ $0,014 \times 100(\%)$; Crude protein content $(\%)=$ Nitrogen content $\times 6.25$.

Determination of mineral elements in maize grain: Mineral elements were analyzed by using Van loon method (1996). One gram of crushed sample was placed in a $250 \mathrm{~mL}$ conical flask, and then added $15 \mathrm{~mL}$ of $\mathrm{HNO}_{3}$ and $5 \mathrm{~mL}$ of concentrated $\mathrm{H}_{2} \mathrm{SO}_{4}$. The solution was well mixed and heated on a stable stove at a temperature of $160^{\circ} \mathrm{C}$ until brown color disappears and white gas appears. Total $10 \mathrm{~mL} \mathrm{H}_{2} \mathrm{O}_{2}$ was added to the mixture and continued to heat until dry. The hydrolyzed sample was cooled and the residue was dissolved slowly with deionized water until reaching solution volume of $100 \mathrm{ml}$. The mineral elements were determined on atomic adsorption spectrophotometers.

\section{Data analysis}

Each experiment was done with 3 replicates and was expressed as the mean value \pm standard deviation. Data were collected and compared using Student $t$-test with significant difference at $\mathrm{P}<0.05$.

\section{RESULTS AND DISCUSSION}

\section{Effect of $\mathrm{nCu}$ treatment on germination of maize seeds}

After seeds treated with $\mathrm{nCu}$ at the optimal and high concentrations, germinated 
rate were $96.8 \%$ for $\mathrm{F} 1$ and $97.2 \%$ for $\mathrm{F} 2$, which means a non-significant result between the treaments and the control (100\%, $P>0.05)$. The germination seed continued to be monitored for germination power, the ability of seeds to grow uniformly after 7 days in the experimental plots. Although the germination rate was similar among treated and control, the germination power of the seeds at F1 was higher than the seeds at F2 and control (96, 90.07 and 90.03\%, respectively) $(\mathrm{P}<0.05)$ (Fig. 1).

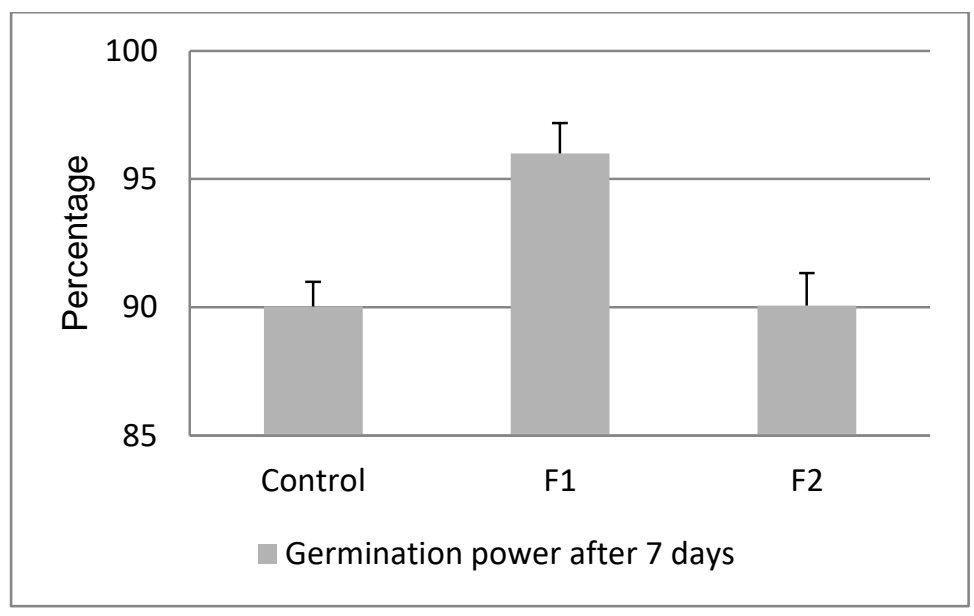

Figure 1. Germination power of $\mathrm{nCu}$ treated LVN 092 seeds

Several studies have been carried out to assess the effect of nanomaterials on cultivated species. Toxicity assesment of 5 nanoparticles (multi-walled carbon nanotubes, aluminum, aluminum compounds, $\mathrm{Zn}$ and $\mathrm{ZnO}$ ) showed that only $\mathrm{Zn}$ and $\mathrm{ZnO}$ nanoparticles inhibited the germination and growing roots of grass and maize plants, respectively, when the concentration of 2000 $\mathrm{mg} / \mathrm{L}$ was used to treat seeds (Lin \& Xing, 2007, 2008). Musante White (2010) discovered $\mathrm{Ag}$ and $\mathrm{Cu}$ nanoparticles to reduce the development of pumpkin plant (Cucurbita pepo). Examinating the effect of $\mathrm{TiO}_{2}$ and $\mathrm{Fe}_{3} \mathrm{O}_{4}$ nanoparticles on tomato plants cultivated in hydroponic system, Giordani et al. (2012) observed the number of root hair of seedlings grown in medium containing $500 \mathrm{mg} / \mathrm{L} \mathrm{TiO}_{2}$ nanoparticles was significant higher than the control plants or the one treated with $50 \mathrm{mg} / \mathrm{L}$ and $500 \mathrm{mg} / \mathrm{L} \quad \mathrm{Fe}_{3} \mathrm{O}_{4}$ nanoparticles; additionally, the treated plants with nanoparticles were not morphologically changed because the toxicity were undetected in plants. Similarly, in our study, $\mathrm{nCu}$ at low and 500 fold higher concentrations did not affect the germination ability of maize seed LVN 092. At the optimum concentration, $\mathrm{nCu}$ even promoted the germination power.

\section{Evaluate the growth and development of maize plants from $\mathrm{nCu}$ treated seeds}

The seedling vigor was uniform among the experimental plots after 14 days planting. The analysis of plant devolopment at 30, 40 and 50 days after growing showed that the plant height in 3 experimental plots did not differ significantly $(\mathrm{P}>0.05)$. Growth rate in the period of 30-40 days was fater compared to the period of 40-50 days and the same for 3 experiment plots during the studied period $(\mathrm{P}>0.05)$ (Table 1). This suggests that $\mathrm{nCu}$ could support seed germination without affecting the plant height as well as plant growth. It also is worth to note that although seeds treated with $\mathrm{nCu}$ at different concentrations, the plants still grow normally as the control together with uniformity morphology in whole develpment period. 
Table 1. Plant growth and development characteristics of $\mathrm{nCu}$ treated seeds

\begin{tabular}{|c|c|c|c|}
\hline & Control & F1 & F2 \\
\hline \multicolumn{4}{|c|}{ Plant height $(\mathrm{cm})$} \\
\hline $30^{\text {th }}$ day & $66,27 \pm 8,07$ & $73,20 \pm 6,40$ & $60,03 \pm 6,72$ \\
\hline $40^{\text {th }}$ day & $138,27 \pm 9,15$ & $139,97 \pm 4,91$ & $139,80 \pm 7,20$ \\
\hline $50^{\text {th }}$ day & $171,20 \pm 9,62$ & $176,80 \pm 7,86$ & $172,50 \pm 3,10$ \\
\hline \multicolumn{4}{|c|}{ Growth rate $($ cm/day) } \\
\hline From $30^{\text {th }}$ to $40^{\text {th }}$ day & $7,20 \pm 1,25$ & $6,68 \pm 0,55$ & $7,98 \pm 0,85$ \\
\hline From $40^{\text {th }}$ to $50^{\text {th }}$ day & $3,29 \pm 1,36$ & $3,69 \pm 0,96$ & $3,27 \pm 0,73$ \\
\hline
\end{tabular}

\section{Analysis of theoretical and actual yields}

Crop productivity is the most important factor for a cultivared crop species. Breeding, fertilizer application, or intensive farming are all aimed at improving productivity. In this study, statistical analysis showed that the theoretical and actual yields in F1 using seeds treated at optimal concentration of $\mathrm{nCu}$ was higher than that of the control $(\mathrm{P}<0.05)$. Above result could prove that $\mathrm{nCu}$ at an optimal concentration not only stimulate seed germination, but also have a positive effect on plant productivity. In addtion, at high concentration of $1000 \mathrm{mg} / \mathrm{kg}$, the yield from treated seeds was not different from that of control. The obtained results of this study are consistent with many other studies concerning the impact of nanoparticles on plant species. Sheykhbaglou et al. (2010) testing the effect of $\mathrm{FeO}$ nanoparticles at concentrations of $0.75 \mathrm{~g} / \mathrm{L}$ and $0.5 \mathrm{~g} / \mathrm{L}$ on agronomic traits of field-grown soybean found that at concentration of $0.5 \mathrm{~g} / \mathrm{L}$, it increased yield to the highest level of $48 \%$ compared to the control. Other studies demonstrated that low concentrations $(20 \mathrm{mg} / \mathrm{L})$ of $\mathrm{TiO}_{2}$ nanoparticles promoted photosynthesis and nitrogen metabolism (Hong et al., 2005a, b; Yang et al., 2006) as well as mRNA replication and protein expression in plant cells leading to increasing the growth of spinach (Gao et al., 2006). It is also noteworthy that the mixture of $\mathrm{SiO}_{2}-\mathrm{TiO}_{2}$ nanomaterials had the ability to increase reductase nitrate enzyme in soybeans, help the plants enhancing the absorption and use of water and fertilizer, stimulating the antioxidant system, germination and growth (Lu et al., 2002). Studies on the transport mechanism and expression level of metal binding genes in germinated rice seeds treated with $\mathrm{Zn}, \mathrm{Fe}, \mathrm{Cu}$ and $\mathrm{Mn}$ nanoparticles indicated that the nanoparticles were transported from the culture medium into the endosperm (part containing starch) of the rice grain, then dispersed to the secondary roots, leaves meristem during whole germination stages of the rice grain via the expression of intermediates nicotianamine (NA) and deoxymugineic acid (DMA) in the biosynthetic pathway of the mugineic acid (MAs) group - phytosiderophores, which plays an important role in the transport and accumulation of metals in grain development process (Takahashi et al., 2009). Recently, Giraldo et al. (2014) announced 3 fold increased in photosynthesis on chloroplasts of Arabidopsis treated with carbon nanotube material encasulated by single strand of DNA. Churilov et al. (2012) and Ngo et al. (2013; 2014) evaluated the effect of metal nanoparticles on the germination and growth of maize and reported that germination rate, leaf surface area, leaf weight, root weight, root length and plant height incresed by 14 ; $22.2 ; 25 ; 27.3 ; 28.3$ and $17.2 \%$, respectively. In addtion, $\mathrm{Fe}, \mathrm{Co}$ and $\mathrm{Cu}$ nanoparticles promote both yield and quality of harvested products. Salama (2012) demonstrated a positive effect of silver nanoparticles on the growth of several crops, including bean (Phaseolus vulgaris L.) and maize. Addition of Ag nanoparticles at concentrations of 20 to 
$60 \mathrm{ppm}$ increased the length of shoots and roots, leaf surface area, chlorophyll, carbohydrate and protein contents of beans and maize.

Table 2. Effect of $\mathrm{nCu}$ on productivity of LVN 092 maize

\begin{tabular}{|l|l|l|l|}
\hline \multicolumn{1}{|c|}{ Traits } & Control & F1 & F2 \\
\hline Weight of 5 ears $(\mathrm{kg})$ & $0,723 \pm 0,025$ & $0,843 \pm 0,021$ & $0,777 \pm 0,051$ \\
\hline Seed weight/ 5 ears $(\mathrm{kg})$ & $0,587 \pm 0,015$ & $0,697 \pm 0,025$ & $0,620 \pm 0,046$ \\
\hline Fresh seed moisture & $24,767 \pm 1,026$ & $24,167 \pm 0,153$ & $25,300 \pm 0,200$ \\
\hline Theoretical yield $(0.1$ ton/ha) & $48,683 \pm 0,607$ & $58,080 \pm 1,482$ & $51,523 \pm 1,865$ \\
\hline Actual yields $(0.1$ ton/ha) & $20,756 \pm 0,259$ & $32,026 \pm 0,817$ & $21,902 \pm 1,709$ \\
\hline
\end{tabular}

Analysis of nutrient content of harvested maize grains

To assess the effect of $\mathrm{nCu}$ on nutrient value, maize grain in each experimental plot was harvested. Moisture, ash, crude fiber and total crude protein contents of seeds were analyzed. The results show that there was no difference of all interested sustances among exprimental plots (Table 3, Fig. 2).

Moisture is the amount of free water in the grain. Small changes in water content may greatly affect the storage life and germination of seeds (Ali et al., 2014). High water content coupled with the presence of oxygen were the main causes of lipid toxicity in seeds leading to rapid quality degradation of storade seeds (Chang, 2004). The suitable water content of maize grain at $25^{\circ} \mathrm{C}$ and relative humidity of $30 \%$ was $8.4 \%$ (Cromarty et al., 1982). In this study, the seed water content in F1 and F2 was not significant diference compared to $8.4 \%$ of the control $(p>0.05)$ and therefore it means $\mathrm{nCu}$ do not inflluent to water content of grain and the seeds obtained from plants grown using $\mathrm{nCu}$ streated seeds maintain as normal seeds.

Ash is the rest of the grain after its organic sustances totally burned. The elements $\mathrm{C}, \mathrm{H}$, $\mathrm{O}, \mathrm{N}$ are lost in the form of $\mathrm{CO}_{2}$, steam, $\mathrm{NO}_{2}$, $\mathrm{O}_{2}$ or $\mathrm{N}_{2}$. The ash contains only mineral salts. The results in table 3 showed that the ash content of maize grains in 3 plots did not differ from each other and valued from 1.4 to
$3.3 \%$ as indicated by Maziya-Dixon et al. (2000).

Fiber in grain consists of 2 parts: (i) soluble fibers including some special compounds called prebiotics including gum, mucilage, pectin are short-chain polysaccharide and can be soluble in water; and (ii) insoluble fibers are long-chain polysaccharides and water-insoluble. In this study, the total fiber content was quite low in all 3 experimental lots.

The crude protein content of corn grain ranges from 9.23 to $9.85 \%$. According to statistical analysis, the crude protein content of grain of F1 and F2 was not different from that of maize in the control plot ( $p>0.05)$. This indicates that using $\mathrm{nCu}$ to treat seeds before sowing did not affect seed quality.

In addition, storage mineral element in seeds have a high biological value to humans, and are essential for grain entering the early stages of germination and growth, direct involvement in building living cells, regulating growth and development in plants. Corn seeds from experimental treatments were analyzed for the content of minerals $\mathrm{K}$, $\mathrm{Ca}, \mathrm{Mg}, \mathrm{Fe}$ and $\mathrm{Zn}$. Results showed that accumulation levels of mineral elements were safe and intoxicated to plants or health of users. The content of $\mathrm{K}$ was the highest, followed by $\mathrm{Mg}, \mathrm{Ca}, \mathrm{Fe}$, and $\mathrm{Zn}$. These results are consistent with the report of Gwirtz \& Garcia-Casal (2014). 


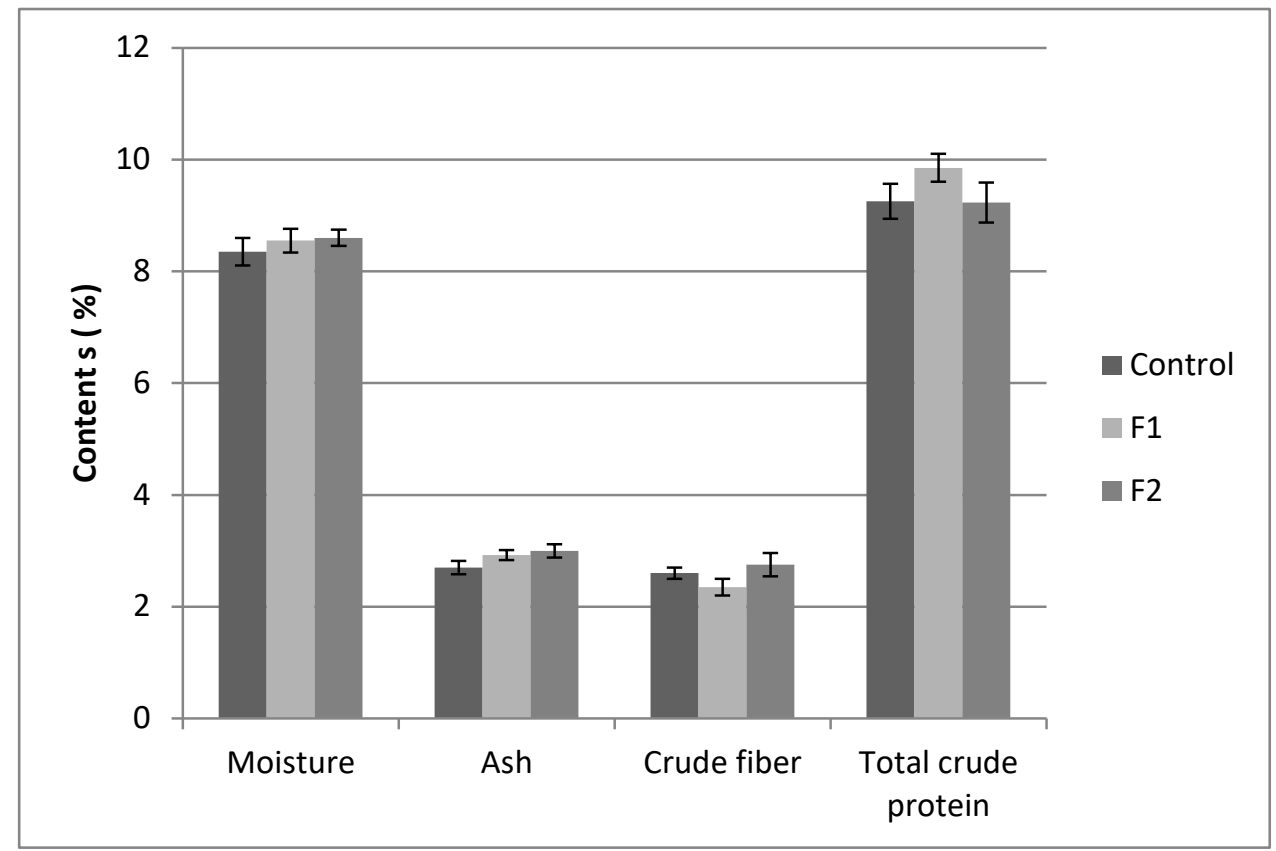

Figure 2. Nutritional quality of grain

\section{CONCLUSION}

Using $\mathrm{nCu}$ at low concentration of 20 $\mathrm{mg} / \mathrm{kg}$ for treatment of maize seeds before planting promoted germination rate, germination power, plant growth and development, that increased productivity and levels of mineral elements compared to the control. Using $\mathrm{nCu}$ of high concentration (e.g. $1000 \mathrm{mg} / \mathrm{kg}$ of seeds) also caused a nonsignificant effect on germination rate, plant growth and development, and nutrient values of the treated seeds.

Acknowledgements: This study was supported by the Key Project for Science and Technology of the Vietnam Academy of Science and Technology "Application of nanotechnology in agriculture"; Component IV: "Study on the mechanism and biosafety assessment of nano products of the project" (code: VAST.TĐ.NANO.04/15-18). We would like to express our great gratitude to Assoc. Prof. Nguyen Hoai Chau, MSc. Dao Trong Hien et al. (Institute of Environmental Technology), Dr. Ha Hong Hanh, MSc. Pham
Le Bich Hang (Institute of Genome Research); Dr. Nguyen Xuan Thang et al. (Maize Research Institute); Dr. Dao Thi Sen et al. (Hanoi University of Education) for their supports.

\section{REFERENCES}

Adhikari T., Biswas A. K., Kundu S., 2010. Nanofertilizer- a new simension in agriculture. Indian J. Fert., 6: 22-24.

Ali M. R., Rahman M. M., Ahammad K. U., 2014. Effect of relative humidity, initial seed moisture content and storage container on soybean (Glycine max L. Meril.) seed quality. Bangladesh J. Agril. Res., 39(3): 461-469.

Alloway B. J., 2008. Zinc in soils and crop nutrition. Second edition. International zinc Association and International Fertilizer Industry Association. Brussels, Belgium and Paris, France, 2008.

AOAC., 1999. Methods of the Association of Official Chemists. Official Methods of 
Analysis (15th ed.). Virginia Association. Official Analytical Chemists, USA, 1141.

Begum P., Ikhtiari R., Fugetsu B., 2014. Potential impact of multi-walled carbon nanotubes exposure to the seedling stage of selected plant species. Nanomaterials, 4: 203-221.

Benjamin E., Grabe D. F., 1988. Development of oven and Karl Fischer techniques for moisture testing of grass seeds. J. Seed. Technol., 12: 76-89.

Chang S. K. C., Liu Z. S., Hou H. J., Wilson L. A., 2004. Influence of storage on the characteristics of soybean, soymilk and tofu. Proc. VII- World Soybean Res. Con., IV-In: Soybean Proc. and Util. Con., IIICongresso Brasileiro de Soja Brazilian Soybean Congress, Foz do Iguassu, PR, Brazil, 29 February-5 March: 977-983.

Churilov G. N., Polischuk S. D., Selivanov V. N., 2000. Application of superdispersive powders of iron, copper and cobalt in plant growing. Mat. $5^{\text {th }}$ All-Russian Conf. on Agriculture. Ekaterinburg, 343-344 (in Russian).

Churilov G. I., 2010. Eco-biological effects of nanocrystalline metals. Dissertation, Ryazan State Medical University. Ryazan City, Russia.

Churilov G. I., Ngo Q. B., Nguyen H. C., 2012. Physiological and biochemical effects of nanocrystalline metals on maize plant. Proc. 6th International Workshop on Advanced Materials Science and Nanotechnology (IWAMSN 2012) - Ha Long City, Vietnam, October 30November 02: 221-224.

Cromarty A. S., Ellis R. H., Roberts E. H., 1982. The design of seed storage facilities for genetic conservation, $96 \mathrm{pp}$. IBPGR, Rome.

Gao F., Hong F., Liu C., Zheng L., Su M., Wu X., Yang F., Wu C., Yang P., 2006.
Mechanism of nano-anatase $\mathrm{TiO}_{2}$ on promoting photosynthetic carbon reaction of spinach. Biol. Trace Elem. Res., 111: 239-253.

Giordani T., Fabrizi A., Guidi L., Natali L., Giunti G, Ravasi F., Cavallini A., Pardossi A. (2012). Response of tomato plants exposed to treatment with nanoparticles. EQA-Environ. Qual., 8: 27-38.

Dong H. G., Dam T. P., Chu H. H., Hoang H., Le V. S., 2013. Synthesis of $\mathrm{TiO} 2$ nanofluid by the sol - gel method and its applications in the tobacco mosaic virus prevention. J. Sci. Devel., 11(6): 790-796.

Giraldo J. P., Landry M. P., Faltermeier S. M., McNicholas T. P., Iverson N. M., Boghossian A. A., Reuel N. F., Hilmer A. J., Sen F., Brew J. A., Strano M. S., 2014. Plant nanobionics approach to augment photosynthesis and biochemical sensing. Nat. Mater., 13: 400-408.

Gwirtz J. A., Garcia-Casal M. N., 2014. Processing maize flour and corn meal food products. Ann. N. Y. Acad. Sci., 1312(1): 66-75.

Hong F., Yang F., Liu C., Gao Q., Wan Z., Gu F., Wu C., Ma Z., Zhou J., Yang P. (2005a). Influence of nano- $\mathrm{TiO}_{2}$ on the chloroplastaging of Spinach under light. Biol. Trace. Elem. Res., 104: 249-260.

Hong F., Zhou J., Liu C., Yang F., Zheng L., Yang P., 2005b. Effects of nano-TiO2 on photochemical reaction of chloroplasts of Spinach. Biol. Trace. Elem. Res., 105: $269-279$.

Kole C., Kole P., Randunu K. M., Choudhary P., Podila R., Ke P. C., Rao A. M., Marcus R. K., 2013. Nanobiotechnology can boost crop production and quality: first evidence from increased plant biomass, fruit yield and phytomedicine content in bitter melon (Momordica charantia). BMC Biotechnol, 13: 37. 
Lin D., Xing B., 2007. Phytotoxicity of nanoparticles: inhibition of seed germination and root growth. Environ. Pollut., 150: 243-250.

Lin D., Xing B., 2008. Root uptake and phytotoxicity of $\mathrm{ZnO}$ nanoparticles. Environ. Sci. Technol., 42: 5580-5585.

Lopez-Moreno M. L., De La Rosa G., Hernandez-Viezcas J. A., Peralta-Videa J. R., Gardea-Torresdey J.L., 2010. X-ray absorption spectroscopy (XAS) corroboration of the uptake and storage of $\mathrm{CeO}_{2}$ nanoparticles and assessment of their differential toxicity in four edible plant species. J. Agric. Food. Chem., 58: 3689-3693.

Lu C. M., Zhang C. Y., Wen J. Q., Wu G. R., Tao M. X., 2002. Research of the effect of nanometer materials on germination and growth enhancement of Glycine max and its mechanism. Soybean Sci., 21: 168-172.

Maziya-Dixon B. B., Kling J. G., Okoruwa A. E., 2000. Physical, chemical and water absorption characteristics of tropical maize hybrids. Afr. Crop. Sci. J., 8: 419-428.

Musante C., White J. C., 2010. Toxicity of silver and copper to Cucurbita pepo: Differential effects of nano and bulk-size particles. Environ. Toxicol., 27: 510-517.

Ngo Q. B., Nguyen H. C., Dao T. H., Tran X. T., Khuu T. D., Nguyen T. T. V, Huynh T. H., 2013. Effects of metal nanopowders $(\mathrm{Fe}, \mathrm{Cu}, \mathrm{Co})$ on the germination, growth and crop yield and product quality of soybean (Vietnamese hybrid species DT51). Proc. 4th International Workshop on Nanotechnology and Application (IWNA 2013)-Vung Tau City, Vietnam, 14-16 Nov. 2013, 296-299.

Ngo Q. B., Dao T. H., Nguyen H. C, Tran X. T., Nguyen T. V., Khuu T. D., Huynh T. H., 2014. Effects of nanocrystalline powders $(\mathrm{Fe}, \mathrm{Co}$, and $\mathrm{Cu})$ on the germination, growth, crop yield and product quality of Soybean (DT-51). Adv. Nat. Sci. Nanosci. Nanotechnol., 5(1): 015016.

Duong T. N., Ho T. T., Nguyen T. T. H., Le K. C., Vu Q. L., Nguyen B. N., Nguyen P. H., Vu T. H., Trinh T. H., Nguyen H. H., Nguyen X. T., Nguyen V. C., Do M. C., Nguyen H. C., Ngo Q. B., 2014. Effects of nanosilver on growth of Chrysanthemum sp., Fragaria sp., and Gerbera sp. cultured in vitro. J. Biotechnology, 1: 103-111.

Duong T. N., Nguyen V. C., Hoang T. T., Nguyen T. T. H., Do M. C., Vu T. H., Nguyen B. N., Nguyen P. H., Vu Q. L., Nguyen H. C, Ngo Q. B., 2015. In vitro growth and development of Chrysanthemum sp. on the iron nano supplemented media. J. Scie. Devel., 13(7): 1162-1172.

Nguyen T. P. P., 2011. Study on the synthesis of $\mathrm{Cu}$ nano solution as material for plant protection pesticides to control pink fungus Corticium salmonicolor, and white powdery mildew Oidium Heveae of rubber trees. Report of Dong Nai Project.

Peteu S. F., Oancea F., Oana A., Sicuia O. A., Constantinescu F., Dinu S., 2010. Responsive polymers for crop protection. Polymers., 2: 229-251.

Rico C. M, Majumdar S., Duarte-Gardea M., Peralta-Videa J. R, Gardea-Torresdey J. L, 2011. Interaction of nanoparticles with edible plants and their possible implications in the food chain. J. Agric. Food. Chem., 59: 3485-3498.

Roduner E., 2006. Size matters: why nanomaterials are different. Chem. Soc. Rev., 35: 583-592.

Salama H. M. H., 2012. Effects of silver nanoparticles in some crop plants, Common bean (Phaseolus vulgaris L.) 
and corn (Zea mays L.). Int. Res. J. Biotech., 3: 190-197.

Sheykhbaglou R., Sedghi M., Shishevan M. T, Sharifi R. S., 2010. Effects of nano-iron oxide particles on agronomic traits of soybean. Notulae. Sci. Biol., 2: 112-113.

Takahashi M., Nozoye T., Kitajima N., Fukuda N., Hokura A., Terada Y., Nakai I., Ishimaru Y., Kobayashi T., Nakanishi H., Nishizawa N. K., 2009. In vivo analysis of metal distribution and expression of metal transporters in rice seed during germination process by microarray and $\mathrm{X}$-ray fluorescence imaging of $\mathrm{Fe}, \mathrm{Zn}, \mathrm{Mn}$, and $\mathrm{Cu}$. Plant. Soil, 325: 39-51.
Hoang T. T., Nguyen P. H., Nguyen B. N., Vu Q. L., Vu T. H., Truong T. B. P., Duong T. N., 2016. Effects of nano silver on growth of Chrysanthemum morifolium in microponic system. J. Biotechnology, 14: 461-471.

Van loon J. C., 1996. Analytical atomic absorption spectroscopy: Selected methods. Academic press, Inc; Ltd; London.

Yang F., Hong F. S., You W. J., Liu C., Gao F. Q., Wu C., Yang P., 2006. Influences of nano-anatase $\mathrm{TiO}_{2}$ on the nitrogen metabolism of growing Spinach. Biol. Trace. Elem. Res., 110: 179-190. 
